\title{
Microcnemum coralloides (Chenopodiaceae- Salicornioideae): an example of intraspecific East-West disjunctions in the Mediterranean region
}

\author{
by \\ Gudrun Kadereit ${ }^{1} \&$ Ahmet Emre Yaprak $^{2}$ \\ ${ }^{1}$ Institut für Spezielle Botanik und Botanischer Garten, Johannes Gutenberg-Universität Mainz, 55099 Mainz, Germany. \\ Corresponding author: clausing@uni-mainz.de \\ ${ }^{2}$ Ankara University, Science Faculty, Department of Biology, Besevler/Ankara, Turkey. aeyaprak@hotmail.com
}

\begin{abstract}
Kadereit, G. \& A.E. Yaprak. 2008. Microcnemum coralloides (Chenopodiaceae-Salicornioideae): an example of intraspecific East-West disjunctions in the Mediterranean region. Anales Jard. Bot. Madrid 65(2): 415-426.

Microcnemum is a monotypic genus of Salicornioideae comprising rare, annual, hygrohalophytic herbs growing in hypersaline inland lagoons and salt pans. Microcnemum coralloides shows an East-West disjunction in the Mediterranean region: $M$. coralloides subsp. coralloides occurs in central and eastern Spain while $M$. coralloides subsp. anatolicum grows in Turkey, Syria, Armenia and Iran. We studied the phylogeny, biogeography and morphological differentiation of $M$. coralloides. Molecular analyses, using five western and eight eastern accessions of the species, were based on three different markers (nuclear ITS and plastid atpB-rbcL spacer and trnT/F region) analysed with Maximum Parsimony and Maximum Likelihood. Estimates of divergence times were calculated using a Likelihood Ratio Test (LRT) and the Penalized Likelihood (PL) method. The two subspecies can be clearly distinguished by their different seed testa surface. Other diagnostic characters were not found. The molecular data (ITS and ML analysis of the trnT/F region) indicate that $M$. coralloides subsp. coralloides originated from within $M$. coralloides subsp. anatolicum which implies an East Mediterranean origin and subsequent westward dispersal. Age estimates for the split of the two subspecies range from 2.8-0.5 million years ago. Considering the relatively low genetic differentiation and the low crown group age (0.7-0.1 mya) of $M$. coralloides subsp. coralloides in comparison to $M$. coralloides subsp. anatolicum we favour the hypothesis that the Iberian part of the species range was established during cold periods of the Early Pleistocene and that the range of the species was fragmented during a warmer period soon after its arrival in Iberia.
\end{abstract}

Keywords: Biogeography, disjunction, Microcnemum, molecular clock, East Mediterranean, Spain.

\section{Resumen}

Kadereit, G. \& A.E. Yaprak. 2008. Microcnemum coralloides (Chenopodiaceae-Salicornioideae): un ejemplo de las disyunciones intraespecíficas Este-Oeste en la región mediterránea. Anales Jard. Bot. Madrid 65(2): 415-426 (en inglés).

Microcnemum es un género monotípico de Salicornioideae que consiste en hierbas higrohalófilas, anuales, raras, que crecen en cuencas endorréicas hipersalinas del interior y salares. Microcnemum coralloides muestran una disyunción Este-Oeste en la región mediterránea: M. coralloides subsp. coralloides aparece en el centro y el levante español, mientras que M.coralloides subsp. anatolicum crece en Turquía, Siria, Armenia e Irán. Estudiamos la filogenia, la biogeografía y la diferenciación morfológica de M. coralloides. Los análisis moleculares, empleando cinco adquisiciones occidentales y ocho orientales de la especie, se basaron en tres marcadores distintos (ITS nuclear, espaciadores plástidos atpBrbcL y región trnT/F) analizados con Máxima Parsimonia y Máxima Verosimilitud. Las estimaciones de tiempos divergentes se calcularon empleando una Prueba de Verosimilitud (LRT) y el método de Verosimilitud Penalizada. Las dos subspecies se distinguen claramente por la diferencia en la superficie de su envoltura. No se encontraron otras características de diferenciación. Los datos moleculares (ITS y análisis ML de la región trnT/F) indican que $M$. coralloides subsp. coralloides originó de dentro de $M$. coralloides subsp. anatolicum, lo cual implica un origen en el este del Mediterráneo y su posterior dispersión hacia el oeste. Las estimaciones de edad para la separación de las dos subespecies data desde hace 2,8 a 0,5 millones de años. En vista de la diferenciación genética, relativamente baja y la reducida edad del grupo terminal (0,7-0,1 millones de años) de $M$. coralloides subsp. coralloides en comparación con $M$. coralloides subsp. anatolicum, favorecemos la hipótesis de que la parte ibérica de la gama de la especie se estableció durante periodos fríos del Bajo Pleistoceno y que la gama de la especie se fragmentó durante un periodo más cálido no mucho después de su llegada a la Península.

Palabras clave: Biogeografía, disyunción, Microcnemum, reloj molecular, Mediterráneo oriental, España. 


\section{Introduction}

Plant species that show an extreme East-West disjunction in the Mediterranean region have been noticed for a long time (Engler, 1879; Willkomm, 1896; Braun-Blanquet \& Bolòs, 1957; Davis \& Hedge, 1971). More recently, also some examples of disjunctly distributed lichens were reported in the literature (Barreno, 1991; Egea \& Alonso, 1996). Additional striking examples come from studies of cave-dwelling Crustaceae (Brehm, 1947), freshwater zooplankton (Miracle, 1982), Coleoptera (Sanmartin, 2003) and from a detailed survey of the insect fauna of the central Monegros region of Spain which listed 62 species showing a disjunct distribution between NE Spain and the steppes in the eastern Mediterranean area or Central Asia (Ribera \& Blasco-Zumeta, 1998). Although molecular and analytical tools are now available to study the origin and age of disjunct distribution patterns, the list of molecular studies which focus on extreme disjunctions of plant species in the Mediterranean is relatively short (but see: Castro \& al., 2002; Carine \& al. 2004; Rosselló \& al., 2007; Thompson, 1999).

Three main explanations have been put forward for extreme East-West disjunctions in the Mediterranean region: 1 . The extant populations have been interpreted as relict populations of a formerly (pre-Pleistocene) continuous or at least wider distribution area, and probably survived in isoclimatic areas of the Mediterranean (Taberlet \& al., 1998) from where some of them again expanded. 2. The extant populations in one part of the disjunct distribution area are the result of colonization through long distance dispersal. The direction of dispersal is usually inferred from the asymmetrical distribution of the specific taxon with the newly colonized area having a smaller expansion (Davis \& Hedge, 1971; Ribera \& BlascoZumeta, 1998; Thompson, 1999). 3. Some taxa are interpreted to be early and undocumented introductions by man (Willkomm, 1896).

Microcnemum is a monotypic genus of Chenopodiaceae subf. Salicornioideae that shows an extreme East-West disjunction in the Mediterranean region. Like most members of Salicornioideae it grows in hygrohalophytic habitats and has succulent, apparently leafless, articulated stems and spike-like inflorescences. Among salicornioidean genera, Microcnemum is characterised by comprising small annual herbs. The bracts subtending three flowers that are free from each other are connate and form a cup-shaped structure. The perianth is reduced to a tiny membranous lobe and the seeds are ovoid, flattened and have a granulose or papillose surface (Aellen, 1967; Molero, 1986, 2000). Of these characters only the minute peri- anth rudiment which disappears in the fruiting stage represents an autapomorphy and is unique in Salicornioideae (Kadereit \& al., 2006).

Microcnemum occurs along the shores of flat, steppic lagoons in extremely saline sites. It often grows on thick salt crusts together with a few other species that are salt-tolerant and able to cope with extreme hypersaline conditions during the dry season. Associated with Microcnemum coralloides in Turkey are, for example, Kalidium foliatum Moq., K. wagenitzii (Aellen) Freitag \& G. Kadereit, Halocnemum strobilaceum M. Bieb., Halimione verrucifera (M. Bieb.) Aellen and Salicornia L. spp. (all Chenopodiaceae), while M. coralloides in Spain often is associated with Halopeplis amplexicaulis Ung.-Sternb., Halocnemum strobilaceum M. Bieb., Artbrocnemum macrostachyum (Moric.) K. Koch and several species of Sarcocornia A.J. Scott and Salicornia (also all Chenopodiaceae). The presence of Microcnemum seems to fluctuate from year to year probably in response to seasonal fluctuations in rainfall (E. Yaprak, pers. obs.; B.M. Crespo, pers. comm.).

Microcnemum coralloides comprises two subspecies. Microcnemum coralloides subsp. coralloides is restricted to inland salt lakes or salt pans in central and eastern Spain (Molero, 1986; Blanché \& Molero, 1990). For some time after its discovery in 1959, M. coralloides subsp. anatolicum was only known from the type locality or nearby (Aellen, 1967). Later it was also recorded from central and NW Iran, the Syrian Desert, Armenia and several new localities in Turkey (Mouterde, 1966; Botschantzev \& Barsegjan, 1972; Gabrielian, 1981; Akhani, 1988; Akhani \& Ghorbanli, 1993; Hamzaoglu \& al., 2005; Yaprak, 2008). Apart from their disjunct distribution, the two subspecies differ only in the structure of the seed testa, which is densely and distinctly papillose in $M$. coralloides subsp. anatolicum (Wagenitz, 1959) but only granulose or slightly papillose in M. coralloides subsp. coralloides (compare Figs. 1-4 in Molero, 1986). Other differences between the two subspecies have never been identified. The type collection of $M$. coralloides subsp. anatolicum, how-ever, was incomplete because the plant was collected in the fruiting stage only (Wagenitz, 1959).

A recent molecular systematic study of subf. Salicornioideae demonstrated that, based on nuclear DNA (ITS), Microcnemum is most closely related to Artbrocnemum Moq. (Kadereit \& al., 2006). Artbrocnemum contains low shrubs that differ from Microcnemum in several characters (e.g., growth form, number of stamens) but also shows some similarities (e.g., shape of the connate bracts, free flowers, membranous perianth; Kadereit \& al., 2006). It is a ditypic genus that is distributed in inland and coastal halo- 
phytic habitats throughout the Mediterranean area, SW Asia and North America. Statistical support for the sister group relationship of these two genera was low, and the topology of chloroplast DNA based trees (atpB-rbcL spacer; Kadereit \& al., 2006) suggests that the closest living relatives of Microcnemum are members either of the Salicornia/Sarcocornia lineage or of the Australian Salicornieae. However, the branches of these four lineages (Artbrocnemum, Microcnemum, Salicornia/Sarcocornia lineage, Australian Salicornieae) are long and diverged more or less simultaneously in the Middle Miocene (19.6-14.6 mya; Kadereit \& al., 2006).

The finding that the two subspecies of Microcnemum represent a lineage that originated during the Middle Miocene, show an extremely disjunct distribution but, at the same time, are morphologically very similar, leads to the following questions: 1 . Are the two subspecies supported by molecular evidence? 2 . Does flower morphology provide additional characters to distinguish the two subspecies? 3. When did the two subspecies separate? 4. Is the distribution found today the result of recent dispersal or is it better explained as a relict of a formerly wider distribution area?

To address these questions we sequenced three different markers from the chloroplast and nuclear genome for five accessions of $M$. coralloides subsp. coralloides and eight accessions of $M$. coralloides subsp. anatolicum. Where a likelihood ratio test (LRT) rejected a model of strict clock-like evolution, we applied a Penalized Likelihood (PL) approach to obtain divergence dates of interest. Additionally, we studied the morphology of the poorly known and rare M. coralloides subsp. anatolicum.

\section{Material and methods}

Plant material for molecular and morphological studies.-The plant material included in the molecular study is listed in Table 1 and the accessions of Microcnemum included in the molecular analyses are mapped in Fig. 1. Altogether 13 accessions of Microcnemum were sampled for ITS and the atpB-rbcL spacer, five from Spain, six from Turkey, one from Iran and one from Armenia. For the $\mathrm{trnT} / \mathrm{F}$ region, one Spanish Microcnemum sample and the Armenian sample failed to amplify and for two samples only a partial sequence was obtained (compare Table 1). Additionally, two accessions of Arthrocnemum macrostachyum, Halosarcia indica (Willd.) Paul G. Wilson, Sarcocornia utahensis (Tidest.) A.J. Scott and Halopeplis amplexicaulis were included in all analyses. According to the results of Kadereit \& al. (2006), Halopeplis served as outgroup in this study. The other lineages included in the analysis are most closely related to Microcnemum.

The material of $M$. coralloides subsp. anatolicum listed in Table 1 was also used for morphological examination.

DNA isolation, amplification, and sequencing.- Total genomic DNA was either isolated from silica gel dried stems or young herbarium material using 20-50 mg. For DNA extraction the NucleoSpin plant DNA extraction kit (Macherey-Nagel) was used following the manufacturer's specifications.

Standard PCR amplification was performed using standard reaction mixes (e.g., Kadereit \& al., 2003) including $0.25-1 \%$ DMSO and c.1 ng/ $\mu$ LNA with a Grant Autogene II-Thermocycler programmed as described in Kadereit \& al. (2005). Amplification products were checked on $0.8 \%$ agarose gels. PCR pro-

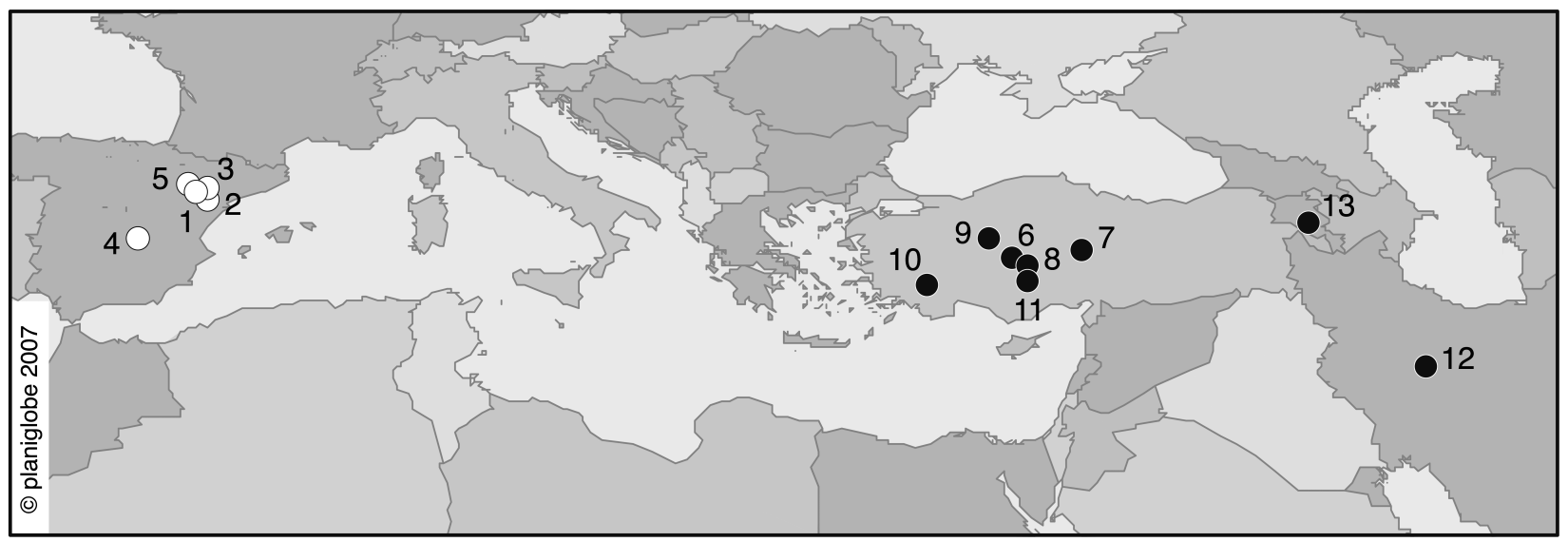

Fig. 1. Localities of Microcnemum coralloides included in the molecular analyses (numbers refer to population numbers listed in Table 1). Microcnemum coralloides subsp. coralloides shows a scattered distribution in central and eastern Spain (compare also http://www. programanthos.org) and M. coralloides subsp. anatolicum has been recorded from a few localities in Turkey, Syria, Armenia and central, eastern and northwestern Iran. 


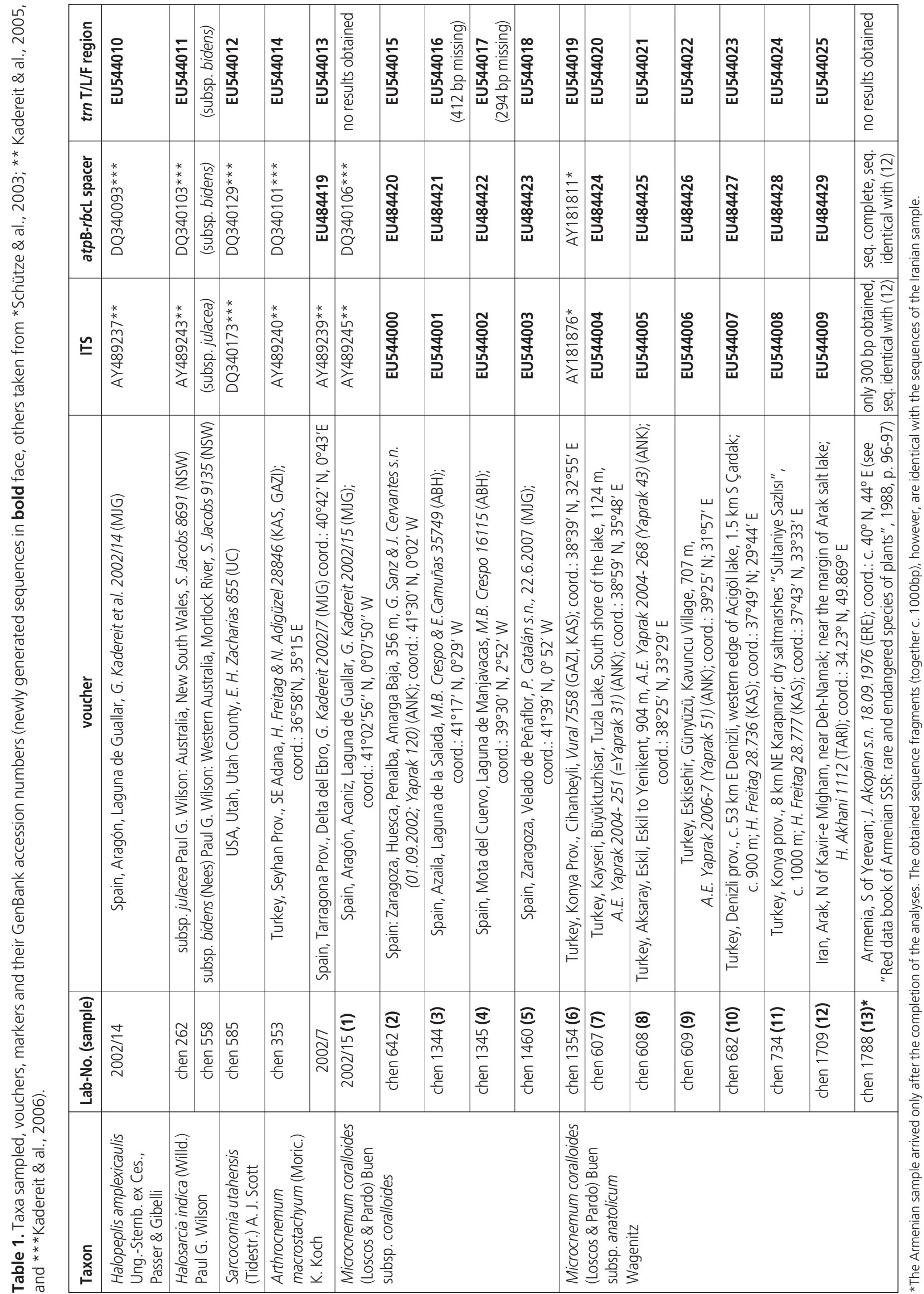


ducts were directly purified with the PCR product purification kit (Macherey-Nagel). PCR primer sequences used for ITS and the $a t p \mathrm{~B}-r b c \mathrm{~L}$ spacer can be found in Kadereit \& al. (2006). The $\operatorname{trn} \mathrm{T} / \mathrm{F}$ region was amplified in three fragments (primer sequences after Taberlet \& al. (1991) if not indicated otherwise): 1. $\operatorname{trn} \mathrm{T}-\mathrm{f}$ ( = ucp-a, forward) and trnL-b (modified for this study, reverse): 5' AAT TCC AGG GTT TCT CTG AAT TTG -3'; 2. ucp-c (forward) and ucp-d (reverse); 3. trnL-460 (after Worberg \& al., 2007) and trn-F (= ucp-f, reverse).

The purified PCR products were sequenced using the ABI Prism Dye Terminator Cycle Sequencing Ready Reaction Kit (Perkin Elmer) and five-fold diluted PCR primers as sequencing primers. For cycle sequencing, thermocyclers were programmed as described in Kadereit \& al. (2005). Extension products were sequenced on ABI 373 or 377 automated sequencers.

Alignment.-Forward and reverse sequences were edited and assembled to consensus sequences which then were aligned using SequencherTM 4.1. The alignments of all markers were straightforward and required little manual correction. Indels were unambiguous and coded in a 0/1 matrix for all markers (compare Table 2). Mononucleotide microsatellites in the cp markers were excluded from the analyses.

Maximum Parsimony analyses.-The matrices were analysed under maximum parsimony (MP) criteria separately and combined. A partition homogeneity

Table 2. Sequence characteristics of the molecular markers used and tree statistics of the Maximum Parsimony analyses.

\begin{tabular}{|c|c|c|c|c|}
\hline Marker & ITS & $\begin{array}{c}\text { atpB-rbcL } \\
\text { spacer }\end{array}$ & $\begin{array}{l}\text { trnT/F } \\
\text { region }\end{array}$ & $\begin{array}{c}\text { combined } \\
\text { data }\end{array}$ \\
\hline $\begin{array}{l}\text { Taxa included } \\
\text { Microcnemum } \\
\text { /other Salicornioideae }\end{array}$ & $12 / 5$ & $12 / 5$ & $11 * 1 / 5$ & $11 * 1 / 5$ \\
\hline Aligned bp & 663 & 744 & 1876 & 3283 \\
\hline $\begin{array}{l}\text { Within Microcnemum } \\
\sum \text { variable sites } \\
\text { Indels/ point mutations } \\
\text { Parsimony informative }\end{array}$ & $\begin{array}{c}10 \\
1 / 9 \\
4\end{array}$ & $\begin{array}{c}8 \\
3 / 5 \\
6\end{array}$ & $\begin{array}{c}31 \\
13 / 18 \\
19\end{array}$ & $\begin{array}{c}49 \\
17 / 32 \\
29\end{array}$ \\
\hline $\begin{array}{l}\text { All taxa analysed } \\
\sum \text { variable sites } \\
\text { Parsimony informative } \\
\text { Tree length } \\
\text { Number of shortest trees } \\
\text { Tree indices }\end{array}$ & $\begin{array}{c}157 \\
79 \\
207 \\
1 \\
\text { Cl } 0.9 \\
\text { RI } 0.89\end{array}$ & 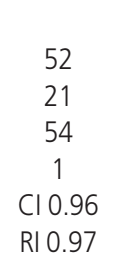 & $\begin{array}{c}178 \\
78 \\
204 \\
21 \\
\text { Cl } 0.90 \\
\text { RI } 0.91\end{array}$ & $\begin{array}{c}387 \\
177 \\
473 \\
18 \\
\text { Cl } 0.89 \\
\text { RI } 0.89\end{array}$ \\
\hline
\end{tabular}

*1 No amplification results for sample 2002/15 of Microcnemum coralloides subsp. anatolicum for the trnT/F region, but sample in the ITS data set identical with sample 642 test (Farris \& al., 1994; implemented in PAUP* 4.0b10) was conducted with 1000 homogeneity replicates and the same heuristic search conditions as described below. All analyses (markers separately and combined) included heuristic searches with 1000 replicates of random taxon addition and tree-bisection-reconnection (TBR) branch swapping. MP Bootstrap was performed under the same conditions as the heuristic search with 1000 replicates of 100 random taxon additions.

Maximum Likelibood analyses.-Maximum likelihood (ML) analyses were conducted for all three data sets and the combined data set using the best-fit substitution model determined by Modeltest 3.06 (Posada \& Crandall, 1998). Maximum likelihood searches were performed with the settings outlined in Table 3 . The heuristic search was performed with TBR branch swapping and 100 random sequence additions. Bootstrap support values were calculated from 100 replicates of heuristic searches again using TBR swapping and 100 random additions of sequences.

Molecular clock analysis.-Age estimates for Salicornioideae published in Kadereit \& al. (2006) were used to calibrate the basal node as indicated in Fig. 2. The age estimates calculated in Kadereit \& al. (2006) used Salicornites massalongoi from Oligocene deposits (35.4-23.3 Mya, Chiavu, Italy; Principi, 1926) as a fossil calibration point and was based on a broad sample of Salicornioideae. Because the study of Kadereit \& al. (2006) was based on ITS and the atpB$r b c \mathrm{~L}$ spacer, the age estimates obtained from these two markers were used for the corresponding data sets here. For the calibration of the $\operatorname{trn} \mathrm{T} / \mathrm{F}$ tree and the tree resulting from the combined analysis the age estimates for ITS and the atpB-rbcL spacer in Kadereit $\&$ al. (2006) were used in combination (22.2-17.8 mya; compare Fig. 2C,D,G,H).

For the estimation of divergence times we used two different approaches: 1. Likelihood ratio test (LRT; Felsenstein, 1988) and 2. Penalized Likelihood (PL) as implemented in "r8s" (Sanderson, 2002). The latter was conducted twice: 1 . based on the tree resulting from the MP analyses and 2. based on the ML trees.

LRT: A likelihood ratio test (Felsenstein, 1988) was conducted for all three data sets and the combined data set. Rate-constancy was tested by calculating log-likelihood scores for trees with and without a molecular clock enforced using PAUP. Non-significance at the 0.01 level between tree topologies, indicating that a molecular clock can not be rejected, was assessed with Modeltest 3.06 (Posada \& Crandall, 1998).

PL: The MP and ML tree topologies shown in Fig. 2 (except the ML tree of the $a t p \mathrm{~B}-r b c \mathrm{~L}$ spacer 

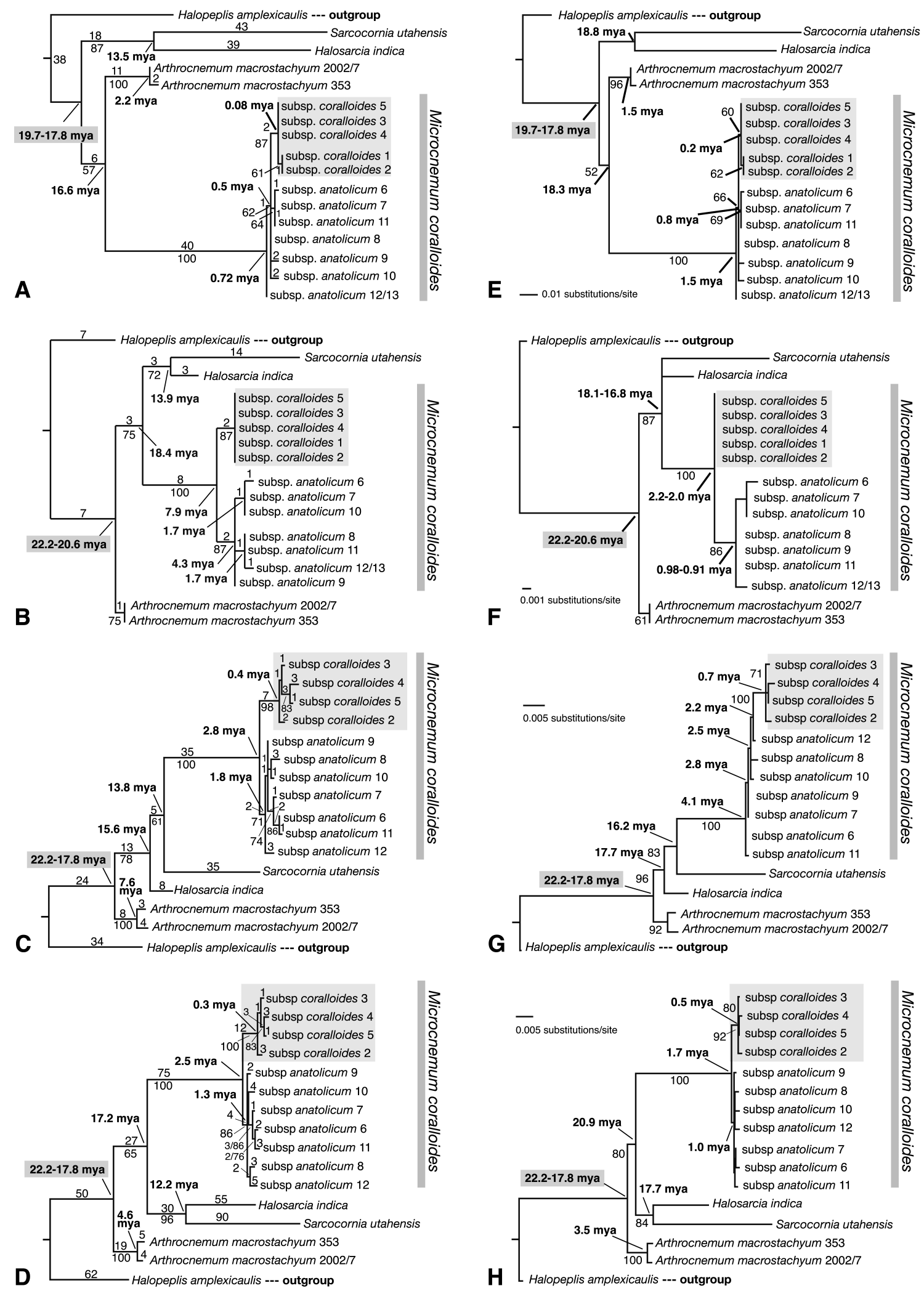

Fig. 2. Phylograms derived from Maximum Parsimony (MP) analyses of the ITS (A), atpB-rbcL spacer (B), trnT/F region (C) and combined data sets (D) as well as Maximum Likelihood (ML) analyses of the ITS (E), atpB-rbcL spacer (F), trnT/F region (G) and combined data sets $\mathbf{( H )}$. Number of character changes are indicated above branches in A-D, MP bootstrap values for A-D and ML bootstrap values for $\mathrm{E}-\mathrm{H}$ below branches. The calibrated node is marked with a grey box, age estimates derived from the Penalized Likelihood method are shown in bold face (except $2 \mathrm{~F}$, here age estimates are derived from the clock-enforced ML tree). The analysis details are summarized in Table 2 and 3, the age estimates are summarized in Table 4. 
Table 3. Settings and results of the Maximum Likelihood analyses and results of a Likelihood ratio test (LRT) conducted for all data set and the combined data set ( $\mathrm{df}=$ degrees of freedom).

\begin{tabular}{|c|c|c|c|c|}
\hline Marker & ITS region & atpB-rbcL spacer & trnT/F region & combined data sets \\
\hline Substitution model & GTR+I & GTR & $\mathrm{GTR}+\mathrm{G}$ & GTR+I \\
\hline Nucleotide frequencies & $\begin{array}{c}\text { A } 0.19 \\
\text { C } 0.296 \\
\text { G } 0.315 \\
\text { T } 0.2\end{array}$ & $\begin{array}{l}\text { A } 0.394 \\
\text { C } 0.139 \\
\text { G } 0.115 \\
\text { T } 0.322\end{array}$ & $\begin{array}{l}\text { A } 0.383 \\
\text { C } 0.140 \\
\text { G } 0.151 \\
\text { T } 0.327\end{array}$ & $\begin{array}{l}\text { A } 0.346 \\
\text { C } 0.171 \\
\text { G } 0.184 \\
\text { T } 0.299\end{array}$ \\
\hline Rate matrix & $\begin{array}{c}\text { AC } 1.052 \\
\text { AG } 6.703 \\
\text { AT } 1.748 \\
\text { CG } 0.422 \\
\text { CT } 2.597 \\
\text { GT } 1.0\end{array}$ & $\begin{array}{c}\text { AC } 0.467 \\
\text { AG } 0.917 \\
\text { AT } 0.082 \\
\text { CG } 0.994 \\
\text { CT } 0.917 \\
\text { GT } 1.0\end{array}$ & $\begin{array}{c}\text { AC } 1.158 \\
\text { AG } 0.903 \\
\text { AT } 0.203 \\
\text { CG } 0.645 \\
\text { CT } 0.903 \\
\text { GT } 1.0\end{array}$ & $\begin{array}{c}\text { AC } 0.932 \\
\text { AG } 01.943 \\
\text { AT } 0.251 \\
\text { CG } 0.703 \\
\text { CT } 1.261 \\
\text { GT } 1.0\end{array}$ \\
\hline Fraction invariable sites or gamma distribution & 0.6368 & 0 & 0.239 & 0.76 \\
\hline No of trees/ML score & $1 / 1738.89$ & $1 / 1189.69$ & $1 / 3363.37$ & $1 / 6576.38$ \\
\hline ML score with clock enforced & 1754.714 & 1200.05 & 3393.0 & 6606.53 \\
\hline Results of LRT & $\begin{array}{c}d f=15 \\
\text { ratio } 31.65 \\
p=0.0072 \\
\text { not clock-like }\end{array}$ & $\begin{array}{c}d f=15 \\
\text { ratio } 20.73 \\
p=0.146 \\
\text { clock-like }\end{array}$ & $\begin{array}{c}\mathrm{df}=14 \\
\text { ratio } 59.34 \\
p<0.0000001 \\
\text { not clock-like }\end{array}$ & $\begin{array}{c}\mathrm{df}=14 \\
\text { ratio } 66.3 \\
p<0.0000001 \\
\text { not clock-like }\end{array}$ \\
\hline
\end{tabular}

which was clock-like) were implemented in the r8s command block together with the following settings: method Penalized Likelihood (PL), algorithm Truncated-Newton (TN) method. For each analysis we performed two runs: 1 . a preliminary run estimating the optimal smoothing parameters with cross validation start set to 0 , cross validation increase set to 0.2 and number of steps $\mathrm{k}=50 ; 2$. the second run implemented the optimal smoothing parameters (MP trees: 1000000 each for ITS, atpB-rbcL spacer and the $\operatorname{trn} \mathrm{T} / \mathrm{F}$ region and 4 for the combined analysis; ML tree: 4 for ITS and combined data set and 10 for the $\operatorname{trn} \mathrm{T} / \mathrm{F}$ region) and estimated the ages of the nodes using the constraints (minimum age, maximum age) as indicated in Fig. 2 (shaded box).

Confidence intervals were calculated for the age estimates of the combined ML tree using r8s (Sanderson, 2002) and the r8s bootstrap kit (Eriksson, 2002). Relative branch length from 100 bootstrapped trees were transformed into 100 absolutes ages. This age distribution was then used to calculate $95 \%$ confidence intervals for the crucial nodes in Microcnemum.

\section{Results}

Morphological data.-Comparison of the morphology of the two subspecies revealed a great overall similarity. After the survey of more material from Turkey (listed in Table 1), the seed testa remains the only unambiguous character to distinguish the two sub- species (Fig. 3, see also Molero, 1986: Figs. 1-4). The Iranian and Armenian specimens included here also show a distinctly papillose seed testa as typical for M. coralloides subsp. anatolicum. Whether the populations growing in Syria have papillose seeds, too, has not been investigated. A more delicate and less branched habit of the eastern subspecies does not consistently distinguish the two taxa because dwarf forms of M. coralloides subsp. coralloides can also be observed in Spain (G. Kadereit, per. obs.; Molero, 2000: 535, Fig. 160a). We found that fertile segments of "well-grown" individuals are usually larger (2.5$3.5 \mathrm{~mm}$ long) in M. coralloides subsp. coralloides than in M. coralloides subsp. anatolicum (1.5-2.2 mm long). Although we also saw flowering material from Turkey, which was unavailable to Wagenitz (1959), we did not find any additional character to delimitate the two subspecies. The number of stamens is one in both. Regarding coloration, we found that although $M$. coralloides subsp. anatolicum never turns crimson, coloration is variable and can not be used as a diagnostic character.

Molecular data.-The partition homogeneity test showed a p-value of 0.03 which means that only $3 \%$ of the artificial partitions resulted in shorter or equally long trees than the original partitions. Therefore, the three data sets do not show a significantly different phylogenetic signal when a level of 0.01 is used.

Sequence characteristics of the molecular markers used and tree statistics of the Maximum Parsimony 

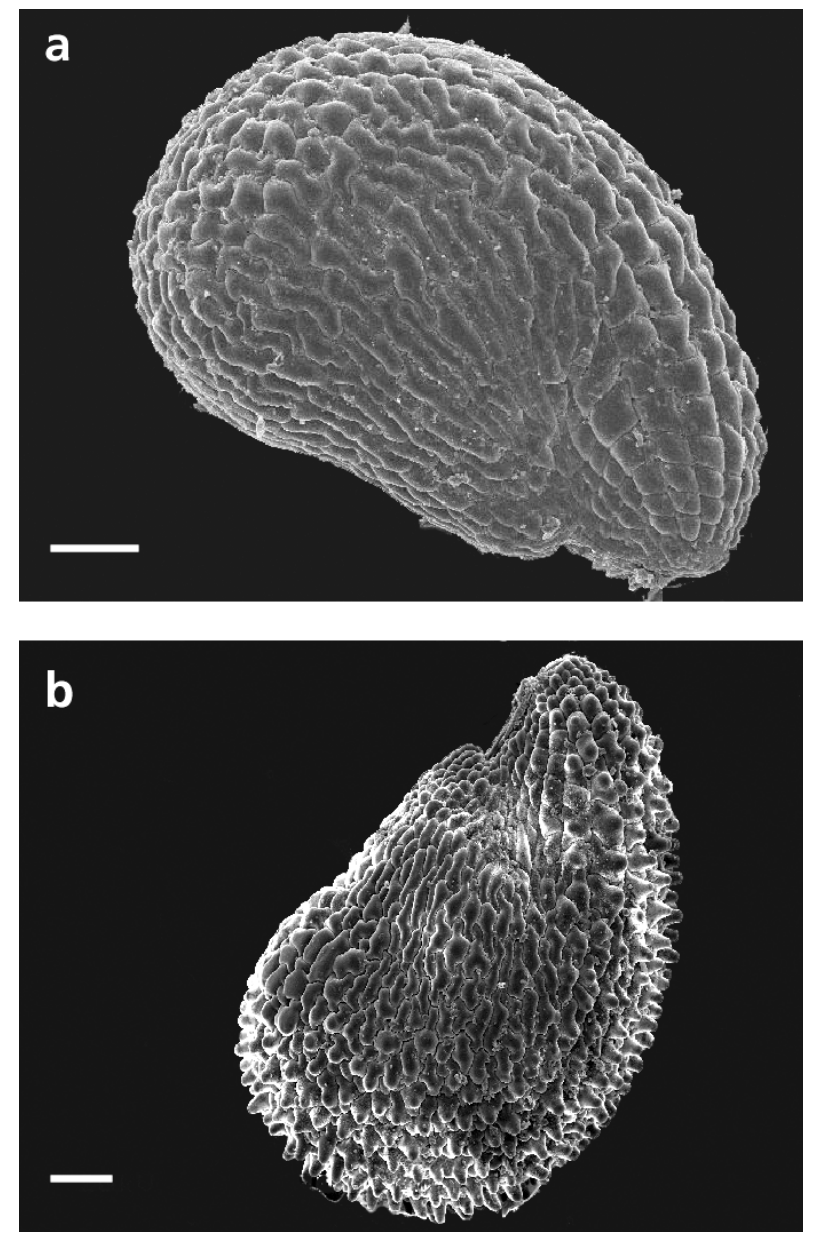

Fig. 3. SEM pictures of seeds of Microcnemum coralloides subsp. coralloides (a, seed taken from sample 2 in Table 1 ) and $M$. coralloides subsp. anatolicum (b, seed taken from sample 8 in Table 1). Scale bars in a and b: $100 \mu \mathrm{m}$.

analyses are summarized in Table 2 . The trees are shown in Fig. 2A-D. The ITS and atpB-rbcL spacer data sets each resulted in only one shortest tree (Fig. 2A,B), and the analysis of the $\operatorname{trn} \mathrm{T} / \mathrm{F}$ region resulted in 21 shortest trees that differed in those clades within the subspecies of Microcnemum which did not receive bootstrap support (Fig. 2C). The combined analysis resulted in 18 equally parsimonious tree topologies, and again differences in topology was found in those branches within the subspecies of $M i$ crocnemum that did not receive bootstrap support (Fig. 2D). The results of the Maximum Likelihood analyses are summarized in Table 3. The trees are shown in Fig. 2E-H.

The main results of the molecular clock analyses are indicated in Fig. 2 and summarized in Tables 3 (LRT) and 4 (age estimates for Microcnemum and confidence intervals for age estimates in the combined $\mathrm{ML})$. Only the $a t p \mathrm{~B}-r b c \mathrm{~L}$ spacer data set was clock- like. Therefore, the PL method was not conducted for the ML tree for this marker. Generally ML tree based age estimates and MP tree based age estimates did not differ strongly except for the $a t p \mathrm{~B}-r b c \mathrm{~L}$ spacer (Fig. 2B,F).

\section{Discussion}

\section{Morphological differentiation between the two subspecies of Microcnemum}

In 1957 Wagenitz (1959) discovered a Turkish population of Microcnemum along the shores of Tuz Gölü (Nigde prov., Turkey). He compared his collections with some Spanish specimens of Microcnemum coralloides and found a great overall similarity. The only differences Wagenitz noted were: 1 ) a more delicate and less branched habit in the Turkish specimens, 2) papillose seeds in the Turkish versus granulate seeds in the Spanish specimens (Fig. 3), and 3) a yellow coloration of the specimens versus crimson or blue-greenish in the Spanish ones. Although Wagenitz collected his material mainly in the fruiting stage, he was able to observe mature anthers which also did not show any differences to the Spanish material. Despite the great similarity of the Turkish and Spanish specimens Wagenitz regarded the differences found sufficient to describe the Turkish material as a new subspecies, $M$. coralloides subsp. anatolicum.

The results of our own morphological study of $M$. coralloides subsp. anatolicum which included several new populations from Turkey and material from Iran and Armenia (Fig. 1, Table 1) fully support the findings of Wagenitz (1959). We also found great overall morphological similarity of M. coralloides subsp. anatolicum with $M$. coralloides subsp. coralloides, including flower morphology. The seed testa is the only consistent character to distinguish them (Fig. 3; Molero, 1986: Figs. 1-4). Slight differences in habit (height, succulence and branching) and coloration do not distinguish the two subspecies reliably and are probably plastic and strongly influenced by seasonal fluctuations of rainfall and salinity. Both subspecies of $M$. coralloides show variation, and grow to only very small size under unfavourable conditions.

\section{Molecular phylogeny of Microcnemum}

The molecular analyses presented here recover the same conflicting phylogenetic relationships of Microcnemum as found by Kadereit \& al. (2006). The ITS data set shows a sister group relationship to Artbrocnemum, albeit with very low support (MP: BS 57\%, ML: BS 52\%), while the atpB-rbcL spacer data set moderately supports a sister group relationships of Microcnemum to a clade comprising Sarcocornia uta- 
bensis (representing the Sarcocornia/Salicornia lineage) and Halosarcia indica (representing the Australian Salicornieae). The analysis of the $\mathrm{trn} \mathrm{T} / \mathrm{F}$ region supports a sister group relationship of Microcnemum to Sarcocornia (MP: BS 61\%; ML: BS 83\%) and the two clades are sister to Halosarcia indica (MP: BS $78 \%$; ML: BS 96\%). In the combined analysis the phylogenetic signal of the atpB-rbcL spacer data set prevails (Fig. 2D,H). This conflict in the relationships of Microcnemum is smaller than it seems. Bootstrap support is low in all three data sets and Microcnemum is best regarded as part of a polytomy including the Sarcocornia/Salicornia lineage, Arthrocnemum and Australian Salicornieae. All four clades originated during the Middle Miocene (Fig. 2) probably in the Tethys area, where three of the four clades are still found today. The molecular data presented here show that Microcnemum originated 20.9-13.8 mya (Table 4).

The relationship between the two subspecies of M. coralloides is resolved in three different ways (Table 4): 1. They are sister to each other [combined analysis (ML; MP), trn T/F region (MP) and atpB$r b c \mathrm{~L}$ spacer (MP)], 2. M. coralloides subsp. anatolicum is paraphyletic in relation to $M$. coralloides subsp. coralloides [ITS (ML, MP), trn T/F region (ML)], 3. relationships are not resolved $[a t p \mathrm{~B}-r b c \mathrm{~L}$ spacer $(\mathrm{ML})$ ]. Considerable genetic diversity among the accessions of $M$. coralloides subsp. coralloides can only be found in the $\operatorname{trn} \mathrm{T} / \mathrm{F}$ region while the accessions of M. coralloides subsp. anatolicum show genetic diversity in all three markers. Therefore, the crown group age of M. coralloides subsp. anatolicum is distinctly older (4.1-0.7 mya) than that of M. coralloides subsp. coralloides (0.7-0.08 mya, Fig. 2, Table 4). Considering the geographical isolation of the two taxa, their molecular differentiation and the presence of at least one distinct diagnostic character, their recognition as subspecies is fully justified.

\section{Biogeography of Microcnemum}

A major aim of this study was to infer the time of separation between M. coralloides subsp. coralloides and M. coralloides subsp. anatolicum. This node received age estimates ranging from 2.8-0.5 mya based on the ML and MP trees and different dating methods (Fig. 2, Table 4). The age of 7.9 mya calculated for the atp B-rbcL spacer based on the MP tree (Fig. 2B) is a clear outlier compared to the other estimates obtained and may well have resulted from the low number of characters of this data set (Tables 2, 4). The ITS age estimates are the youngest, and the ML tree dated with the PL method of the $\operatorname{trn} \mathrm{T} / \mathrm{F}$ region yielded the oldest estimates. Recent intersubspecific introgres- sion of ITS as a possible explanation of the young age estimates obtained from this marker seems unlikely in view of the great geographical distance between the two subspecies.

The young age estimate for the ITS data set may also result from an unusual mutation rate. However, comparison with the ITS mutation rates (average: $4.13 \times 10^{-9} \mathrm{subs} /$ site/year; range: $1.72-8.34 \times 10^{-9}$ subs/site/year) found for herbaceous plants (Kay \& al., 2006) shows that the estimated rates for all $M i$ crocnemum samples (3.0-4.3 × $10^{-9}$ subs/site/year) lie well within this range and close to the average rate.

Probably the most objective and possible accurate estimate with the present data is that of the combined analysis, which incorporates all characters available and balances marker specific rate variation among clades. In the two combined trees the split is dated to 2.5 (MP) and 1.7 (ML) mya, respectively. In the combined ML analysis the split of the two subspecies is dated to 1.7 mya with the $95 \%$ confidence interval ranging from 2.17-1.28 mya (Table 4).

A split between the two subspecies around 2.5-1.5 mya as indicated by the combined analyses would imply a separation shortly before, or at the onset of, the Pleistocene. Like Wagenitz (1959), we therefore exclude recent long distance dispersal or anthropogenic introduction to Spain as explanations for the disjunction of Microcnemum. Both explanations can be rejected because of the genetic distinctness of M. coralloides subsp. coralloides (12 mutations in the combined analysis, Fig. 2D) and its intrasubspecific diversification at least in the $\operatorname{trn} \mathrm{T} / \mathrm{F}$ region (Fig. 2C,G).

Microcnemum coralloides shows an extremely scattered distribution in both parts of its range. As outlined in the introduction, the species is restricted to inland lagoons with extreme salinity regimes where it is associated with a few other plant species (mostly Chenopodiaceae) able to tolerate hypersaline conditions. The habitat of Microcnemum is likely to have been available only in isolated localities throughout the past, although it may have been more widespread during the Messinian crisis of the Late Miocene (Krijsman \& al., 1999; Duggen \& al., 2003; Thompson, 2005) and during cooler and drier periods of the Pleistocene (Shackleton \& al., 1984; Lang, 1994; Van Andel \& Tzedakis, 1996).

Two explanations can be offered for the disjunct distribution of Microcnemum:

1) Microcnemum was widely and more or less continuously distributed in the Mediterranean area since the Late Miocene. Such distribution range was fragmented by the onset of the climatic oscillations at the beginning of the Pleistocene. Together with other non frost-tolerant plants Microcnemum was restricted to areas with suitable climatic conditions. Such areas ex- 
Table 4. Age of Microcnemum and dating the split of the two subspecies (in my): 1. Results of molecular clock analyses [ML clock = age estimates are derived from the clock-enforced ML tree (LRT = Likelihood Ratio Test), PL method = Penalized Likelihood method as implemented in r8s, anat. = M. coralloides subsp. anatolicum, cora. = M. coralloides subsp. coralloides]; 2 . Confidence intervals for the combined ML tree (Fig. 2H).

\begin{tabular}{|c|c|c|c|c|c|}
\hline & Marker & ITS region & atpB-rbcL spacer & trnT/F region & combined data sets \\
\hline & $\begin{array}{l}\text { Relationships of the } \\
\text { two subspecies of } \\
\text { M. coralloides (see } \\
\text { also Fig. 2) }\end{array}$ & $\begin{array}{l}\text { M. coralloides subsp. } \\
\text { coralloides nested within } \\
\text { M. coralloides subsp. } \\
\text { anatolicum }\end{array}$ & $\begin{array}{l}\text { Sister group relationship } \\
\text { in MP analysis not } \\
\text { resolved in ML analysis }\end{array}$ & $\begin{array}{l}\text { Sister group relationship } \\
\text { in MP; M. coralloides } \\
\text { subsp. coralloides nested } \\
\text { within M. coralloides } \\
\text { subsp. anatolicum in ML }\end{array}$ & Sister group relationship \\
\hline \multicolumn{6}{|c|}{ ML clock } \\
\hline & $\begin{array}{l}\text { LRT (Table } 3 \text { ) } \\
\text { stem age genus } \\
\text { stem age subsp. } \\
\text { split betw. subsp. }\end{array}$ & not clock-like & $\begin{array}{c}\text { clock-like } \\
18.1-16.8 \\
\text { both } 2.2-2.0 \\
2.2-2.0\end{array}$ & not clock-like & not clock-like \\
\hline \multicolumn{6}{|c|}{ PL method with ML tree } \\
\hline & $\begin{array}{l}\text { stem age genus } \\
\text { stem age subsp. } \\
\text { split betw. subsp. }\end{array}$ & $\begin{array}{c}18.3 \\
\text { anat. } 1.5 \\
\text { cora. } 0.8 \\
0.8\end{array}$ & $\star 1$ & $\begin{array}{c}16.2 \\
\text { anat. } 4.1 \\
\text { cora. } 2.3 \\
2.2\end{array}$ & $\begin{array}{c}20.9 \\
\text { both } 1.7 \\
1.7\end{array}$ \\
\hline \multicolumn{6}{|c|}{ PL method with MP tree } \\
\hline & $\begin{array}{l}\text { stem age genus } \\
\text { stem age subsp. } \\
\text { split betw. subsp. }\end{array}$ & $\begin{array}{c}16.6 \\
\text { anat. } 0.7 \\
\text { cora. } 0.5 \\
0.5\end{array}$ & $\begin{array}{c}18.4 \\
\text { both } 7.9 \\
7.9\end{array}$ & $\begin{array}{c}13.8 \\
\text { both } 2.8 \\
2.8\end{array}$ & $\begin{array}{c}17.2 \\
\text { both } 2.5 \\
2.5\end{array}$ \\
\hline & \multicolumn{5}{|c|}{ Confidence Intervals ( $\mathrm{Cl})$ for the combined ML tree (Fig. $2 \mathrm{H}$ ) } \\
\hline & \multicolumn{5}{|c|}{$\begin{array}{l}\text { Microcnemum stem Cl: } 19.0-22.5(\text { mean }=20.8) \\
\text { subsp. coralloides crown Cl: } 0.33-0.72(\text { mean }=0.53) \\
\text { subsp. anatolicum crown Cl: } 0.71-1.26(\text { mean }=0.98) \\
\text { split of the two subspecies Cl: } 1.28-2.17(\text { mean }=1.73)\end{array}$} \\
\hline
\end{tabular}

*1 PL estimate not needed because LRT was clock-like

isted in southern Spain, southern Sicily, southern Anatolia, SW Asia and N Africa (Van Andel \& Tzedakis, 1996). This would imply that extant sites of the species in central and eastern Spain were re-colonized from localities in southern Spain.

2) Alternatively, it seems possible that the Iberian part of the distribution range of Microcnemum was established only at the onset of the Pleistocene. In cold periods of the Pleistocene the sea level fell and large coastal plains emerged (Shackleton \& al., 1984; Lang, 1994; Van Andel \& Tzedakis, 1996). At such times saline lagoons probably were frequent along the lower and shallow coast lines and could have allowed migration of hygrohalophytic taxa such as Microcnemum.

Considering the paraphyly of M. coralloides subsp. anatolicum in relation to M. coralloides subsp. coralloides in the ITS and $t r n \mathrm{~T} / \mathrm{F}$ trees (Fig. 2A,E,G), the stronger genetic differentiation of subsp. anatolicum in comparison to subsp. coralloides in all three markers, and the higher crown group age of the former
(Fig. 2), we prefer the second of the above two hypotheses and postulate that the Iberian part of the range of $M$. coralloides was established at the onset of the Pleistocene. Such explanation requires that although conditions during cold parts of the early Pleistocene allowed migration over long distances, gene flow between different parts of the distribution range was interrupted soon after the arrival of the species in Iberia. The alternative explanation, Pleistocene fragmentation of a wider distribution area, fails to explain the asymmetrical distribution of genetic diversity seen today, unless additional factors such as population bottlenecks are advocated.

Although Microcnemum is a rather extreme example of an intraspecific East-West disjunction in the Mediterranean region, it is not a singular case. More than 70 examples in c. 25 different plant families can be found in the literature (Engler, 1879: 53-57; Willkomm 1896: 103-104; Tab. 1 "oriental plants"; Davis \& Hedge, 1971; Greuter \& al., 1984, 1986, 1989).

However, only few examples have been analysed 
with molecular tools. Sanmartin (2003) concluded that the Pachydeminae (Coleoptera, Scarabaeoidea), a group of beetles disjunctly distributed in the East and West Mediterranean area, originated in the southeast Mediterranean region and initially diversified in the Middle East and Iran-Afghanistan region. The presence of the group in the Iberian Peninsula was interpreted as a result of migration through North Africa and Gibraltar during the Late Miocene. A molecular study of Buxus balearica Lam. (Rosselló \& al., 2007) using ITS sequence data found a clear geographical split between western and eastern accessions of the species. The molecular data and the ecology of B. balearica as a non cold-tolerant shrub restricted to mesic environments support the hypothesis that the few extant populations in Anatolia (fomerly separated as Buxus longifolia Boiss.) are relicts of a fomerly wider distribution area. Unfortunately, this study does not estimate the date of the split between western and eastern populations.

\section{Acknowledgements}

We are grateful to J. Akopian (Yerevan), M. Assadi (Teheran), P. Catalán (Zaragoza), M.B. Crespo (Alicante), H. Freitag (Kassel) D. Gómez (Jaca) and J. Mehregan (Mainz) for supplying the rare and hard to find material of M. coralloides. We thank N. Munevver Pinar (Ankara), B. Niethard (Mainz), D. Franke (Mainz) and E. Westberg for various technical help. We thank J.J. Aldasoro (Madrid), F. Blattner (Gatersleben), P. Catalán (Zaragoza), H. Freitag (Kassel), J. W. Kadereit (Mainz), G. Schneeweiss (Vienna) and P. Vargas (Madrid) for critically reading and substantially improving the manuscript. A research visit of A.E. Yaprak to Mainz in 2005 was supported by the DAAD (German Academic Exchange Service).

\section{References}

Aellen, P. 1967. Microcnemum Ung.-Sternb. In: Davis, P.H. (ed.), Flora of Turkey and the East Aegean Islands 2:324. Edinburgh University Press. Edinburgh.

Akhani, H. 1988. Plant records from Kavire-Meyghan (Arak), new to Iran. The Iranian Journal of Botany 4: 105-107.

Akhani, H. \& Ghorbanli, M. 1993. A contribution to the halophytic vegetation and flora of Iran. In: Lieth, H. \& Al Masoom, A. (eds.), Towards the rational use of high salinity tolerant plants 1:35-44. Kluwer Academic Publishers. Netherlands.

Barreno, E. 1991. Phytogeography of terricolous lichens in the Iberian Peninsula and the Canary Islands. Botanika Chronika 10: 199-210.

Blanché, C. \& Molero, J. 1990: Halopeplis amplexicaulis (Vahl) Ung.-Sternb. ex Cesati, Passer \& Gibelli. Fragmenta chorologica occidentalia, 2638-2655. Anales Jardín Botánico Madrid 47: 480-481.

Botschantzev, V.P. \& Barsegjan, A.M. 1972. Microcnemum Ung.Sternb. - new genus of the U. S. S. R. flora. Botaničeskij Zurnal 57:504.

Braun-Blanquet, J. \& de Bolós, O. 1957. Les groupements vege- taux du bassin moyen de l'Ebre et leur dynamisme. Anales Estacion Experimental de Aula Dei 5: 1-266.

Brehm, V. 1947. Reflexiones sobre relaciones zoogeográficas de la fauna de agua dulce de la Península Ibérica. Publicaciones Instituto de Biologia Aplicada 4: 53-74.

Carine, M.A., Russell, S.J., Santos-Guerra, A. \& Francisco-Ortega, J. 2004. Relationships of the Macaronesian and Mediterranean floras: molecular evidence for multiple colonizations into Macaronesia and back-colonization of the continent in Convolvulus (Convolvulaceae). American Journal of Botany 91: 1070-1085.

Castro, O. de, Cozzolino, S.L., Jury, S.L. \& Caputo, P. 2002. Molecular relationships in Genista L. sect. Spartocarpus Spach (Fabaceae). Plant Systematics and Evolution 231: 91-108.

Davis, P.H. \& Hedge, I.C. 1971. Floristic links between N. W. Africa and S. W. Asia. Annalen Naturbistorisches Museum Wien 75: 43-57.

Duggen, S., Hoernie, K., van den Bogard, P., Rüpke, L. \& Morgan, J.P. 2003. Deep roots of the Messinian salinity crisis. Nature 422: 602-606.

Egea, J.M. \& Alonso, F.L. 1996. Patrones de distribución en la flora liquénica xerófila del sureste de España. Acta Botanica Malacitana 21:35-47.

Engler, A. 1879 (reprint 1972). Versuch einer Entwicklungsgeschichte der extratropischen Florengebiete der nördlichen Hemisphäre. Engelmann. Leipzig.

Eriksson, T. 2002. R8s bootstrap kit. http://www.bergianska.se/ index_forskning_soft.html.

Farris, J.S., Källersjö, M., Kluge, A.G. \& Bult, C. 1994. Testing significance of incongruence. Cladistics 10:315-319.

Felsenstein, J. 1988. Phylogenies from molecular sequences: inference and reliability. Annual Review of Genetics 22: 521-565.

Gabrielian, E.T.S. 1981. The conservation of rare, threatened species and types of vegetation in Armenia. Anales Jardin Botánico de Madrid 37: 773-778.

Greuter, W., Burdet, H.M. \& Long, G. 1984. Med-Checklist Pteridophyta (ed. 2) Gymnospermae Dicotyledones (AcanthaceaeCneoraceae). Conservatoire et Jardin botaniques de la Ville de Genève. Genève.

Greuter W., Burdet, H.M. \& Long, G. 1986. Med-Checklist 3 Dicotyledones (Convolvulaceae-Labiatae). Conservatoire et Jardin botaniques de la Ville de Genève. Genève.

Greuter, W., Burdet, H.M. \& Long, G. 1989. Med-Checklist 4 Dicotyledones (Lauraceae- Rhamnaceae). Conservatoire et Jardin botaniques de la Ville de Genéve. Genéve.

Hamzaoglu, E., Duran, A. \& Akhani, H. 2005. A new genus record for the Flora of Turkey: Tetradiclis Stev. ex M. Bieb. (Zygophyllaceae). Turkish Journal of Botany 29: 403-407.

Kadereit, G., Borsch, T., Weising, K. \& Freitag, H. 2003. Phylogeny of Amaranthaceae and Chenopodiaceae and the evolution of C4 photosynthesis. International Journal of Plant Sciences 164: 959-986.

Kadereit, G., Gotzek, D., Jacobs, S. \& Freitag, H. 2005. Origin and age of Australian Chenopodiaceae. Organisms, Diversity, and Evolution 5: 59-80.

Kadereit, G., Mucina, L. \& Freitag, H. 2006. Phylogeny of Salicornioideae (Chenopodiaceae): diversification, biogeography, and evolutionary trends in leaf and flower morphology. Taxon 55: 617-642.

Kay, M.K., Whittall, J.B., Hodges, S.A. 2006. A survey of nuclear ribosomal internal transcribed spacer substitution rates across angiosperms: an approximate molecular clock with life history effects. BMC Evolutionray Biology 6: 36. 
Krijgsman, W., Hilgen, F.J., Raffi, I., Sierro, F.J. \& Wilson, D.S. 1999. Chronology, causes and progression of the Messinian salinity crisis. Nature 400: 652-655.

Lang, G. 1994. Quartäre Vegetationsgeschichte Europas. Fischer. Jena, Stuttgart, New York.

Miracle, M. 1982. Biogeography of the freshwater zooplanktonic communities of Spain. Journal of Biogeograpby 9: 455-467.

Molero, J. 1986. Taxonomía del género Microcnemum Ung. Sternb. Collectanea Botanica 16: 327-336.

Molero, J. 2000. 18. Microcnemum Ung.-Sternb.. In: Castroviejo, S. \& al. (eds.), Flora iberica 2: 534-536. Real Jardín Botánico, CSIC. Madrid.

Mouterde, P.S.J. 1966. Nouvelle flore du Liban et de la Syrie. Édition de L'Imprimerie Catholique. Beyrouth.

Posada, D. \& Crandall, K.A. 1998. Modeltest: testing the model of DNA substitution. Bioinformatics 14: 817-818.

Principi, P. 1926. La flora oligocenica de Chiavon e Salcedo. In: Ministerio dell'Economia Nazionale R. Ufficio Geologico (ed.), Memorie della carta geologica d'Italia, 10. Provveditorato Generale dello Stato, Libreria, Roma.

Ribera, I. \& Blasco-Zumeta, J. 1998. Biogeographical links between steppe insects in the Monegros region (Aragón, NE Spain), the eastern Mediterranean, and central Asia. Journal of Biogeography 25: 969-986.

Rosselló, J.A., Lázaro, A., Cosín, R. \& Molins, A. 2007. A phylogeographic split in Buxus balearica (Buxaceae) as evidenced by nuclear ribosomal markers: when ITS paralogues are welcome. Journal of Molecular Evolution 64: 143-157.

Sanderson, M.S. 2002. Estimating absolute rates of molecular evolution and divergence times: A penalized likelihood approach. Molecular Biology and Evolution 19: 101-109.

Sanmartin, I. 2003. Dispersal vs. vicariance in the Mediterranean: historical biogeography of the Palearctic Pachydeminae (Coleoptera, Scarabaeoidea). Journal of Biogeography 30: 1883-1897.

Schütze, P., Freitag, H. \& Weising, K. 2003. A integrated molecular and morphological study of the subfamily Suaedoideae Ulbr. (Chenopodiaceae). Plant Systematics and Evolution 239:
257-286

Shackleton, J.C., van Andel, T.H. \& Runnels, C.N. 1984. Coastal paleography of the central and western Mediterranean during the last 125,000 years and its archaeological implications. Journal of Field Archaeology 11: 307-314.

Taberlet, P., Gielly, L., Pautou, G. \& Bouvet, J. 1991. Universal primers for amplification of three non-coding regions of chloroplast DNA. Plant Molecular Biology 17: 1105-1109.

Taberlet, P., Fumagalli, L., Wust-Saucy, A.G. \& Cosson, J.F. 1998. Comparative phylogeography and postglacial colonization routes in Europe. Molecular Ecology 7: 453-464.

Thompson, J.D. 1999: Population differentiation in Mediterranean plants: insights into colonization history and the evolution and conservation of endemic species. Heredity 82: 229-236.

Thompson, J.D. 2005. Plant evolution in the Mediterranean. Oxford University Press Inc. New York.

Van Andel, T.H. \& Tzedakis, P.C. 1996. Palaeolithic landscapes of Europe and environs 150,000-25,000 Years ago: an overview. Quaternary Science Reviews 15: 481-500.

Wagenitz, G. 1959. Neue und bemerkenswerte Chenopodiaceen Inneranatoliens. Berichte der Deutschen Botanischen Gesellschaft 72: 152-158.

Willkomm, M. 1896. Grundzüge der Pflanzenverbreitung auf der Iberischen Halbinsel. In: Engler, A. \& Drude, O. (eds.), Vegetation der Erde 1. Engelmann. Leipzig.

Worberg, A., Quandt, D., Barniske, A.M., Löhne, C., Hilu, K.W. \& Borsch, T. 2007. Phylogeny of basal eudicots: Insights from non-coding and rapidly evolving DNA. Organisms, Diversity and Evolution 7: 55-77.

Yaprak, A.E. 2008. On the distribution of Microcnemum coralloides (Loscos \& Pardo) Buen subsp. anatolicum Wagenitz (Chenopodiaceae) Wagenitz in Turkey. Journal of Applied Biological Sciences 2: 85-87.

Associate Editor: P. Catalán

Received: 4-III-2008

Accepted: 21-VII-2008 